\title{
Technical and Vocational Education and Training Policy in Zimbabwean Secondary Schools: Teachers' Views
}

\author{
Michael Mhlanga, John Tenha, Francis Ndlovu \\ Lecturer, Faculty of Education, Zimbabwe Open University \\ *Corresponding Author: Michael Mhlanga, Lecturer, Faculty of Education, Zimbabwe Open University

\begin{abstract}
This study sought to investigate the way how schools offering the TVET subjects are implementing the programme in Zimbabwe using the quantitative methodology. The study adopted the descriptive survey design. The target population comprised all secondary school teachers in Seke District. The sample consisted of 240 teachers of which 136 were female and 104 were male. The information was gathered through a questionnaire. The study revealed that most teachers had a positive attitude towards the TVET programme. It also revealed that schools faced many challenges as they tried to implement TVET. The study recommends that there should be more allocation of financial material and human resources towards TVET in schools.
\end{abstract}

Keywords: Technical education, Vocational education, Secondary schools, Implementation, District, HEXCO

\section{INTRODUCTION}

Technical and vocational education and training (TVET) has emerged as one of the most effective human resource development strategies that African countries need to embrace in order to train and modernize their technical workforce for rapid indistrialisation and national development (Afeti, 2014). In almost all countries in Africa, large numbers of graduates coming out of the formal school system are unemployed, although opportunities for skilled workers do exist in the economy (Baiyin, 2004). This situation has brought into sharp focus the mismatch between what schools offer and labour market skill demands (Savage, 2009). Another reason that is often cited for the incidence of high unemployment among graduates is the absence of entrepreneurial training in the school curriculum (Afeti, 2014). In Zimbabwe, technical and vocational education and training gained currency when some secondary schools offered technical and vocational subjects designed by the Higher Education Examination Council (HEXCO). HEXCO curricula are designed in close consultation with industry and all National Foundation Certificates (NFC) courses offered in secondary schools therefore, were characterized by their relevance to industry and commerce (Zendera, 2013). Furthermore, to strengthen the teaching and learning of technical and vocational education in schools, the Ministry of Primary and Secondary Education has adopted and is implementing a two-pathway education structure. The two-pathway structure, which is technically and vocationally biased is meant for post Basic Education (Form 2) to cater for students of different abilities (Policy Circular Number 77 of 2006). All secondary schools in Zimbabwe, therefore, are mandated by this policy pronouncement to teach technical and vocational subjects to all their pupils. It is on account of this information that this study set out to investigate challenges that schools encounter as they attempt to implement this policy.

\section{LiterATURE REVIEW}

Vocational and technical education and training is about work and training for work (Raymond, 2007). Immaculate (2006) in his opinion said that technical and vocational education are work experiences meant to be imparted to an individual systematically in order to get him or her adequately equipped for good employment in a recognized occupation. According to Brickmen (2006), vocational and technical education and training includes numerous occupational areas such as agriculture, various trades, health services and technical training. On the other hand, Nwogu and Nwanoruo (2011) perceive vocational technical educational and training as an educational training which has been designed technically and systematically to accommodate both the trainer and the 
trainee in order to enable most importantly, the trainee acquire the basic knowledge, skills abilities, understanding and attitudes needed for one's efficient performance in his/her chosen occupational carrier for self-reliance and national development.

According to Mpofu (2012) the 2001 United Nations Educational, Scientific and Cultural Organisations (UNESCO) and Interntional Labour Organisations (ILO) General Conference on Technical and Vocational Education and Training (2002) TVET involves those aspects of the educational process in addition to general education, the study of technologies and knowledge related to occupations in various sectors of economic and social life (Foster, 2007). Societal and economic development depends on the strength of TVET provision through the education system as it provides access to skills and entry routes into the labour markets (Nyerere, 2009). Savage (2009) states that TVET includes technical education which essentially refers to theoretical vocational preparation of students for jobs involving applied science and modern technology. It emphasizes the understanding of basic principles of science and mathematics and their practical application rather than the actual attainment of proficiency in manual skills as is the case with vocational education (Savage, 2009). Vocational education and training on the other hand, prepare learners for jobs that are based on manual and practical activities, traditionally non-theoretical and totally related to specific trades, occupations, or vocation (Pillay, 2005).

The technical and vocational education implementation as an education strategy requires substantial financial commitments and dedicated key stakeholders' support and commitment (Bennel, 2009). Investing in a strong, public technical and vocational education and training (TVET) sector must be crucial in knowledge-based societies in developed as well as developing countries (Baiyin, 2004). The UNESCO (2001) revised recommendations on TVET, assert that, given the immense scientific, technological and socio-economic development, either in progress or envisaged, which characterize the present era, particularly globalization and the revolution in Information Communication Technology, TVET should be given central role in the educational process in all countries as it enriches a person for life and it provides the competencies which are necessary in modern states (Savage, 2009).

According to findings by Fuller (2006), not only can TVET support the socio-economic welfare of individuals, but it can also increase their international competitiveness. Currently, as Gatawa (2009) argues, technological changes are taking place at an extremely fast pace in a fast globalizing world. The gap in knowledge and ownership of advanced technologies between developing and developed countries has always been large, with developing countries often adopting technologies and solutions innovated elsewhere and lacking the capacity and resources to adapt most of the technologies to the local context (Bennel, 2009). Transfer of knowledge therefore through TVET coupled with creative skills and career guidance, can raise the innovative capacity of developing countries allowing them to innovate quality technological solutions for their own context and for export and keep up with the developed world (Zendera, 2013).

There are many challenges that schools trying to implement TVET face particularly in developing countries. For example, as Immaculate (2006) postulates, technical and vocational education has been considered as a career path for the less academically endowed, and this perception has been fuelled by the low academic requirements for admissions into TVET programmes and the limited prospects for further education and professional development. As Zendera (2013) observes, what worsens this perception is that governments create the impression that the primary objective of vocational education programme is to keep drop outs; that is, students who are unable to move up the educational ladder, not because of poor grades, but because of lack of places at the higher level from the basic and secondary school systems off the streets, rather than projecting the project as an effective strategy to train skilled workers for the employment market and for sustainable livelihoods.

The other challenge with TVET programmes is that they are competing with academic subjects. Academic education is found by most students and parents to provide a route to better jobs and incomes than other forms of education (Pillay, 2005). With this is mind, students were likely to have a negative attitude towards TVET. As Gichira (2002) posits, aspects such as high probability of getting employment after following a certain course of education results in students developing positive attitudes towards the learning content. 
Fuller (2006) notes that inadequate technical experts to drive TVET systems is another challenge militating against effective TVET provision. There is general lack of professional specialist teachers, education managers and policy makers with adequate expertise and insight in the formulation and implementation of vocational education and training programmes (Gichira, 2002). The TVET staff in many countries lacked the technical capacity to develop national qualifications, courses, competencybased curricula and training packages as well as quality assurance and accreditation standards in TVET (Zendera, 2013).

\section{Statement of the Problem}

Numerous attempts to vocationalise the secondary school education system before and after independence in Zimbabwe have been made without much success. This study sought to examine the extent to which secondary schools are implementing the new TVET policy in Zimbabwe.

\section{Purpose of The Study}

The study sought to establish teachers' perceptions on challenges that their schools faced during the implementation of the technical and vocational education and training programme in order to come up with practical suggestions to improve the situation.

\section{RESEARCH QUESTIONS}

1. What are the teachers' views toward technical and vocational education and training?

2. What are the challenges faced by schools in implementing the TVET programme.

3. How can schools be assisted to better implement the TVET programme?

\section{SIGNIFICANCE OF THE STUDY}

The study's importance is premised on the assumption that if TVET programmes' implementation challenges are established; this would enable all stakeholders to put their heads together to come up with strategies to improve the situation.

\section{Limitations OF THE STUDY}

The study employed a relatively small sample to make generalisations about the whole of Zimbabwe. The other limitation has to do with the descriptive method that was used in this study. According to Kumar (2008), the descriptive method lacks predictive power, the research may discover and describe "what is" but is unable to predict "what would be". The respondents may also give false responses thereby affecting the validity of the findings.

\section{DELIMITATIONS OF THE STUDY}

The study was delimited to teachers' perceptions on challenges faced by rural secondary schools in the implementation of technical and vocational education and training (TVET) using a sample of 120 teachers from Seke District in Zimbabwe. Perceptions from other stakeholders like heads of schools, parents, education officers and pupils were outside the purview of this study.

\section{RESEARCH METHODOLOGY}

The study adopted the quantitative research paradigm and made use of a descriptive survey research design. According to Creswell (2009) the descriptive survey design looks with intense accuracy at the phenomenon of the moment and then describes precisely what the researcher sees. The questionnaire was used as the instrument for collecting data. As Chawawa (2012) observes, the questionnaire increases reliability because of its greater impersonality. However, as Bell (2011) posits, its major weakness is that it may invite people to lie and answer questions vaguely. This was mitigated through the use of pilot testing of the questionnaire. The sample consisted of 120 teachers of which 68 were female and 52 were male. Simple random sampling was used to select the respondents.

\section{Data COLlection And ANALYSis}

Data were collected by means of a questionnaire which was largely made up of close-ended questions and one open-ended question. The questionnaire was chosen because as Blumberg (2008) postulates, it has the ability to reach many respondents who live at widely dispersed addresses and preserves 
Technical and Vocational Education and Training Policy in Zimbabwean Secondary Schools: Teachers' Views

anonymity which encourages greater honesty. However, as Anderson (2011) posits, the questionnaire generally has a low response rate and is inflexible in that it does not allow ideas or comments to be explored in-depth and many questions may remain unanswered. The researchers personally distributed the questionnaires to the schools understudy. The same method was used to collect the completed questionnaires in order to maximize on the rate of return of the instrument. Non-returns as Borg and Gall (2012) argue, introduce a bias in as much as they are likely to differ in many ways from respondents thereby adversely affecting reliability and validity of the findings. Data produced from the questionnaire produced descriptive statistics around the variables under study. These statistics were computed and inferential implications from them derived and recorded.

\section{FINDINGS AND DisCUSSION}

The study set out to explore teachers' perceptions on challenges faced by rural secondary schools in the implementation of the technical and vocational education and training policy in Zimbabwe. This section is presented in two parts, namely, presentation of data and discussion.

\section{Presentation of Data}

Table1. Distribution of Respondents by $\operatorname{Sex}(N=240)$

\begin{tabular}{|l|l|l|}
\hline Sex & Frequency & Percentage \\
\hline Male & 104 & 43 \\
Female & 136 & 57 \\
\hline Total & $\mathbf{2 4 0}$ & $\mathbf{1 0 0}$ \\
\hline
\end{tabular}

Table 1 above shows that there were more female respondents than male ones. The datum was considered statistically significant to the extent that it confirmed that most schools in Zimbabwe had more female teachers than male ones.

Table2. Composition of Respondents by Age $(N=240)$

\begin{tabular}{|l|l|l|}
\hline Age in Years & Frequency & Percentage \\
\hline Below 20 & 4 & 2 \\
\hline $20-29$ & 20 & 8 \\
\hline $30-39$ & 100 & 42 \\
\hline $40-49$ & 108 & 45 \\
\hline 50 and above & 8 & 3 \\
\hline Total & $\mathbf{2 4 0}$ & $\mathbf{1 0 0}$ \\
\hline
\end{tabular}

The information on table 2 above reveals that the majority of the respondents are within the $30-49$ age range (87\%). Those below 30 years constituted $10 \%$ of the respondents and the 50 and above age range were a mere $3 \%$ of the sample.

Table3. Composition of Respondents by Areas of Specializations $(N=240)$

\begin{tabular}{|l|l|l|}
\hline Area of Specialisation & Frequency & Percentage \\
\hline Arts & 188 & 79 \\
Sciences & 36 & 15 \\
Practicals & 8 & 3 \\
Technical & 8 & 3 \\
\hline Total & $\mathbf{2 4 0}$ & $\mathbf{1 0 0}$ \\
\hline
\end{tabular}

Table 3 above shows that the majority of teachers in the sample (79\%) specialized to teach Arts subjects, $15 \%$ specialized to teach sciences and those who specialiased to teach practical and technical subjects were $3 \%$ apiece.

Table4. Composition of respondents by TVET subjects taught $(N=240)$

\begin{tabular}{|l|l|l|}
\hline Subject & Frequency & Percentage \\
\hline Agriculture & 20 & 8 \\
\hline Woodwork & 30 & 12 \\
\hline Metalwork & 10 & 4 \\
\hline Food and nutrition & 20 & 8 \\
\hline Fashion and Fabrics & 14 & 7 \\
\hline
\end{tabular}


Technical and Vocational Education and Training Policy in Zimbabwean Secondary Schools: Teachers' Views

\begin{tabular}{|l|l|l|}
\hline Technical graphics & 10 & 4 \\
\hline Building & 8 & 3 \\
\hline Computer studies & 30 & 13 \\
\hline Accounts & 20 & 8 \\
\hline Physical education & 24 & 10 \\
\hline Art and craft & 14 & 7 \\
\hline N/A & 40 & 16 \\
\hline Total & $\mathbf{2 4 0}$ & $\mathbf{1 0 0}$ \\
\hline
\end{tabular}

The information on table 4 above shows that the majority of respondents (84\%) teach one practical or technical subject or the other and yet the majority of them do not hold qualifications to teach these areas as depicted in table 3 above. Only 16\% of the respondents indicated that they did not teach practical subjects.

Table5. Challenges faced by teachers in TVET implementation $(N=240)$

\begin{tabular}{|l|l|l|l|}
\hline Rank & Challenge & Frequency & Percentage \\
\hline 1 & Lack of expertise & 48 & 20 \\
\hline 2 & Lack of equipment & 44 & 18 \\
\hline 3 & Shortage of textbooks & 40 & 16 \\
\hline 4 & Shortage of specialist rooms & 30 & 13 \\
\hline 5 & Inadequate time & 26 & 11 \\
\hline 6 & Lack of industrial attachment & 20 & 8 \\
\hline 7 & Inadequate funding & 16 & 7 \\
\hline 8 & Students' negative attitudes & 12 & 5 \\
\hline 9 & Lack of parental support & 4 & 2 \\
\hline Totals & & $\mathbf{2 4 0}$ & $\mathbf{1 0 0}$ \\
\hline
\end{tabular}

The information on table 5 above shows the major challenges faced by teachers ranked according to the highest to the lowest frequencies. The picture reveals that many respondents $(20 \%)$ were challenged by lack of expertise to teach TVTE curricula, followed by lack of equipment (18\%), shortage of basic books (16\%), shortage of specialist rooms (13\%), lack of industrial attachment, for pupils $(8 \%)$, inadequate funding $(8 \%)$, students' negative attitudes $(5 \%)$ as well as lack of parental support $(2 \%)$.

The questionnaire had one open-ended question which wanted to find out from the respondents what they felt could be done to improve the implementation of TVET programmmes in their schools. The most common responses included the following: -

- Technical and vocational education and training subjects should be made compulsory for all pupils.

- There should be career guidance for pupils so that they appreciate the value of these subjects.

- Schools should engage other stakeholders particularly industry for attachment of pupils.

- Schools within zones and clusters should collaborate to assist each other on these subjects.

- Schools should be electrified and also have generators on stand by since most of these subjects require electricity.

- Colleges and universities should train more TVET teachers.

- Provide incentives for TVET teachers to attract them to teach in the rural areas.

\section{DISCUSSION}

The findings reveal that the majority of teachers in the study were female. This information was considered statistically significant to the extent that it confirmed that most schools in Zimbabwe had more female teachers than male ones. The implications of this finding are that boys may be disadvantaged if most female teachers specialised in those practical and technical areas viewed by students (boys) as courses for girls. Such stereotypes are common in schools where you find very few boys doing areas like needlework, cookery or fashion and fabrics, because the boys, through 
socialization view them as feminine subjects. This is corroborated by observations by Bennel (2009) who discovered that the socialization of most African boys discouraged them from doing those subjects that their culture preserved for the girls.

The study revealed that the majority of respondents specialized in Arts subjects. Very few teachers under study had specialized in practical and technical subjects. This corroborates information by Zendera (2013) who states that one factor militating against effective implementation of TVET provision in schools is general lack of professional specialist teachers. The nature of technical and vocational subjects is such that those teachers who teach them should have undergone rigorous training to acquire the necessary skills and knowledge to impart to pupils and not just the theoretical aspects of the areas.

Data from the study also reveal that the majority of teachers were assigned to teach one practical subject or the other. This, inspite of the fact that the majority of the teachers were not qualified to teach these subject areas. The effects of this information are that, first of all, pupils receive inadequate information from these ill equipped teachers; secondly; the teachers are forced by authorities to teach these areas because under normal circumstances no teacher would opt to teach in an area where they are fully aware of their lack of capacity. This then breeds a lot of conflict and animosity between teachers and heads of schools. As Raymond (2007) argued, where teachers are compelled to teach there is always bound to be passive resistance through teaching the basics at the expense of core material on the subject thereby disadvantaging the learners.

The study revealed that schools experience a multiplicity of challenges during the implementation of TVET programmes. These challenges among others, included lack of expertise amongst the teachers, lack of equipment to properly teach the subjects, shortage of specialist rooms for the practical teaching of these subjects, inadequate time due to shortage of qualified teachers since the subjects are taught by teachers who teach in other areas, failure by schools to find industrial attachment for their pupils, lack of funding as well as lack of support from parents. The above challenges render the whole implementation process of the TVET programmes an impossible mission. This finding tallies with observations by Bennel (2009) who postulates that technical and vocational education implementation as an education strategy requires substantial financial commitments and dedicated key stakeholders' support and commitment.

Data from the study also revealed that most students and parents had negative attitudes towards the technical and vocational subjects. Where students were expected to choose subject areas (for example at Form Three level) with a combination of academic and practical subjects, the majority opted for the academic areas in spite of the advice from teachers. Where they were coerced to take these subjects, in most cases, they would not register them for the Ordinary Level Examinations as parents would be said to have discouraged them from registering for them. This is corroborated by observations by Pillay (2005) who states that, the other challenge with TVET programmes is that they are competing with academic subjects. Academic education is found by most students and parents to provide a route to better jobs and incomes than other forms of education. With this in mind, students were likely to have a negative attitude towards TVET. As Gichura (2002) argues, aspects such as high probability of getting employment after following a certain course of education results in students developing positive attitudes towards the learning content.

\section{Conclusions}

Given the background of the above findings, the researchers make the following conclusions:

- Both theoretical and empirical data in this study converge on the fact that most Zimbabwean secondary schools are struggling to implement the technical and vocational education and training policy.

- The majority of teachers assigned to teach practical and technical subjects were not in possession of the required qualifications to effectively implement the policy.

- There is lack of equipment in the schools to properly teach pupils the full aspects of TVET in the schools. 
- Schools do not have specialist rooms for the practical activities for the TVET programmes.

- Most schools find it difficult to secure places for industrial attachment for their pupils.

- Schools lack the financial resources to adequately implement TVET programmes.

- Most students and parents had negative attitudes towards the technical and vocational subjects.

\section{RECOMMENDATIONS}

In light of the findings of this study, the researchers would like to make some recommendations.

- The Ministry of Primary and Secondary Education should provide appropriate and adequate material resources like equipment, consumables and textbooks, to ensure effective implementation of TVET in schools.

- The corporate sector should be engaged and requested to adopt certain disadvantaged schools so as to support their TVET programmes.

- Universities like the Zimbabwe Open University should be contracted to publish modules to provide TVET study materials using their state of the art printing machines at lower costs.

- There should be TVET district based education officers to guide heads and teachers on the implementation of TVET programmes.

- In order to develop business operational skills among the pupils, and enhance chances of selfemployment, entrepreneurship courses should be an integral part of TVET courses.

- Schools should have fully functional guidance and counselling departments or units to guide pupils on various career paths including opportunities availed by TVET courses.

\section{REFERENCES}

Afeti, G. (2014). Technical and vocational evaluation and training for industrialization in Africa. Lagos: Research and Resource Forum.

Anderson, L. (2011). Research in education. Sydney: Allen Unwin.

Baiyin, Y. (2004). Holistic learning theory and implications for human resource development. Advance in Developing Human Resources Journal, 24 (6) 242-261.

Bassey, I. E. (2009). Recreating primary education for patriotism and self-reliance. Implications for teacher education. Journal of Qualitative Education, 5(1) 7-14.

Bell, J. (2011). Doing your research methods. Buckingham: Open University.

Bennel, P. (2009). Learning to change: Skills development among the vulnerable and socially Excluded in developing countries. Geneva: Employment and Training Council.

Blumberg, C. (2008). Research methods. Boston: Irwin.

Borg, W. R. and Gall, M. D. (2012). Educational research: An introduction. New York: Havard Brace Publishing Company.

Chawawa, M. (2012). TVET program implementation. Harare: Zimbabwe Open University.

Cresswell, J. W. (2009). Research design: Quantitative, qualitative and mixed methods. Thousand Oaks; C.A: Sage Publications.

Foster, P. J. (2007). Vocational school fallacy in developing countries. New York: Oxford University Press.

Fuller, W. A. (2006). Pre-employment vocational trade training: The case of India. London: Falmer Press.

Gatawa, B.B.S. (1999). The politics of social curriculum: An introduction. Harare: College Press.

Gichira, R. (2002). Ensuring relevance and quality in TVET and entrepreneurship education. Nairobi: Government Press.

Immaculate, E. E. (2006). The funding needs of vocational and technical education programmes in Nigeria's school system. JONATT, 6 (2) 18-21.

Kumar, F. S. (2008). Research in educational settings. London: University of London.

Mpofu, P.C. (2012). Vocational and technical curriculum versus the academic curriculum. Harare: University of Zimbabwe. 
Technical and Vocational Education and Training Policy in Zimbabwean Secondary Schools: Teachers' Views

Nwogu, P. O. and Nwanoruo, C. C. (2011). Vovational technical education and training for self-Reliance: Towards national development. Mediterranean Journal of Social Sciences, Vol (2) 55-59.

Nyerere, J. (2009). Education and training (TVET) sector mapping in Kenya: Zero Draft. Nairobi: Dutch Schokland TVET programme. Educans Foundation.

Pillay, G. F. (2005). Technical and vocational (TVET) systems of selected East Asian countries. Washington DC: The World Bank.

Policy Circular No. 77 of 2006. The two-pathway education process in Zimbabwe's secondary schools. Harare: Government Printers.

Raymond, E. (2007). Constraints affecting electronics of roadsite technicians in Mirna Metropolist. JONATT. 6 (2) $8-14$.

Savage, T. V. (2009). Teaching self-control through management and discipline. Boston Allyn and Bacon.

Zendera, E. (2013). Technical and vocational education and training policy implementation in secondary schools. Harare: Zimbabwe Open University.

Citation: Michael Mhlanga et al.. "Technical and Vocational Education and Training Policy in Zimbabwean Secondary Schools: Teachers' Views" International Journal of Humanities Social Sciences and Education (IJHSSE), vol 8, no. 7, 2021, pp. 111-118. doi: https://doi.org/10.20431/2349-0381.0807013.

Copyright: (C) 2021 Authors. This is an open-access article distributed under the terms of the Creative Commons Attribution License, which permits unrestricted use, distribution, and reproduction in any medium, provided the original author and source are credited. 